\title{
Attachment as Character Education in Boarding School
}

\author{
Adang Darmawan Achmad \\ Islamic Educational Psychology \\ Universitas Muhammadiyah Yogyakarta \\ Yogyakarta, Indonesia \\ Achmad1711@gmail.com
}

\author{
Syarifan Nurjan \\ Islamic Educational Psychology \\ Universitas Muhammadiyah Yogyakarta \\ Yogyakarta, Indonesia \\ syarifan_flo@yahoo.com
}

\begin{abstract}
Boarding school is the educational institution where students not only learn, but also residing and living together at the institute. This research is a field reseach designed to determine analysis in the characteir formation of students in MTs-MA Boarding School Foundation Assunnah Cirebon, with used qualitative analysis of its multidisciplinary approach. informants in this study is from the foundation, business institution that is a determinant of educational policy, school committees, school principals, teachers, and some students are characterless. The results of this study can be concluded that Islamic Boarding School Assunnah Spreading propaganda Islamiyah through tashfiyah and tarbiyah with salafussholeh understanding, Education characters developed is the integration of character education in learning and dormitories, Attachment student-teacher, tilmidz- ustad/ustadzah, and students-committee has an important role in the formation of the character of students, the contribution of education Boarding School by planting six character education Indonesia and the hallmark of character education, in the form of understanding the salaf, compliance, independence, discipline, sincerity, simplicity, islamic brotherhood, submission and obedience.
\end{abstract}

\section{Keywords: Attachment, Character Education, Boarding School}

\section{INTRODUCTION}

Pesantren or other term boarding school is one of the Islamic educational institutions were born in the archipelago and in accordance with Indonesian culture. The pattern of development of the pesantren in conjunction with the pattern Islam inter to Indonesia, which stems from kuttab, halaqah, mosques, until boarding. Since the end of the 15th century Islam had replaced Hinduism, even in the 16th century the majority of the Java community have embraced Islam marked by the establishment of the kingdom of Demak. Under the influence of Islam, Religion of Java education system was taken over and replaced with the values and teachings of Islam. At that time, the education system is a Java Religion "Pawiyatan" [1].

Boarding school is the educational institution where students not only learn, but also residing and living together at the institute. Historically, boarding school refers to classic British boarding school. The term boarding school in several different countries, Great Britain (college), United States (private school), Malaysia (college) and others. Elements or components boarding school consists of physical and nonphysical. Physical component consists of religious facilities, classrooms and dormitories. While the non-physical components in the form of a program of activities arranged in neat, all of predetermined rules and penalties attached to them as well as the quality-oriented education.

MTs-MA Boarding School Foundation Assunnah Cirebon is one of the Boarding School which has educated its students in education MTs with 4 study groups and MA with the 3 study groups each year enrollment. Primary education is to educate the students to follow the teachings of the Prophet in everyday life with the implementation of science and technology, thus combining IMTAK and science and technology that make students compete in the global life with akhlakul karimah. The goals to be achieved in this research to: (1) know the general picture character education of students, (2) analyze the attachment student-teacher and studentmanager in shaping the character of students, (3) analyze the contribution of character education Boarding School on character education in Indonesia.

\section{BASIC THEORY}

1. Boarding School

Historically, boarding school refers to classic British boarding school. The term boarding school in several different countries, Great Britain (college), United States (private school), Malaysia (college) and soon [2]. Elements or components boarding school consists of physical and non-physical. Physical components consist of: religious facilities, classrooms and dormitories. and non-physical components in the form of a program of activities arranged in neat, all of predetermined rules and penalties attached to them as well as on the quality of education orientation (academic quality, teachers, program selection, management, facilities, and others).

Boarding School is a school that has dormitories, where students live; studied in total in the school environment. Therefore, all kinds of needs and learning needs are provided by the school [3]. 


\section{a. Pesantren and history in Indonesia}

Pesantren means the place of the students [4]. The term "boarding school" comes from the students, which is a study Islamic religion, so schools have meaning where people gather to learn about Islam [5]. Pesantren definitively interpreted as Islamic educational institution with the dormitory system or cottage, where clerics as a central figure, mosque as center at the heart, and instruction in Islam under the guidance of religious scholars who followed the students as their main activities.

\section{b. Character Education at Boarding}

Judging from the original saying, "character" is a concept derived from the Greek word "charassein", which means to carve thus forming a pattern. Having a good character, can not be unloaded after birth, but require a long process through parenting and education. Ibn Miskawai (W. 421H / 1030 AD) as the leading expert said morality that morality is inherently embedded in the soul that prompted him to do the deed without requiring thought and consideration.

\section{Characters}

\section{a. Definition of Character}

Etymologically, the word character (English: character) is derived from the Greek, namely charassein which means "to Engrave" [6]. In Indonesian Dictionary the word "character" is defined by character, psychological traits, morals or manners that distinguish one person to another, and character.

Characters can also mean letters, numbers, spaces, special symbols that can be displayed on the screen with the keyboard [7]. Characterless people means people with personality, behavior, character, temper, or disposition. With meaning as this means synonymous with the character's personality or character. In terminological meaning of the character expressed by Thomas Lickona. He said the character is "A reliable inner disposition to respond to situations in a morally good way.""Character so conceived has three interrelated parts: moral knowing, moralfeeling, and moral behavior" [8]. In other words, character refers to a series of cognitives, attitudes, and motivations, and behaviors and skills.

\section{b. Basics Character Education}

In the Qor'an found a lot of the main points of the primacy of the character that can be used to distinguish the behavior of a Muslim, as a command to do good (ihsan) and virtue (al-birr), keeping promises (alwafa), patient, honest, afraid of Allah., charity in the path of Allah, to do justice, and forgiving (QS. al-Qasas [28]: 77; QS. al-Baqarah [2]: 177; QS. al-Muminun (23): 1-11; QS. al-Nur [24]: 37; QS. al-Furqan [25]: 3537; QS. al-Fath [48]: 39; and QS. Ali 'Imran [3]: 134).

\section{c. Character Education Model}

Character education model in the adolescent studied by [9] have developed a model of integration in the application of the directive speech acts noble akhlak education and national character otf the studen in SMA Muhammadiyah 1 Ponorogo in East Java, namely:

1) model of speech acts directive head schools, educators and academic staff to students can be classified into three categories: commands, requests and suggestions,

2) the model (command) actualized in action: forbid, warn, to instruct, admonish, urge, and require,

3) demand model (request) actualized in action: begging, hoping, asking, urging and inviting,

4) models suggestion (suggest) conducted in the advise, encourage, offer, encourage, invite and recommend.

\section{Attachment}

\section{a. Definitions Attachment}

The term attachment for the first time stated by a psychologist from Britain in 1958 named John Bowlby. Ainsworth (in Jonathan Hart and Alicia Limka, 2010: 67 ) says that the attachment is emotional bond formed an individual with others that are specific, binding them in an eternal proximity all the time.

\section{b. The Importance of Attachment.}

Much research has studied the importance of attachment in the development of the individual. [9] that the researchers studied the development of attachment relationships from time to time and to correlate patterns of attachment with subsequent behavior. Attachment has been associated with the exploratory behavior and its impact on learning [9]. A correlation has been shown between attachment patterns and behavioral problems and there are implications of attachment to the behavior at school [9].

\section{METHOD}

This research is a field riseach designed to determine the attachment analysis in the character formation of students in MTs-MA Boarding School Foundation Assunnah Cirebon, with used qualitative analysis of its multidisciplinary approach. Informants in this study is from the foundation, business institution that is a determinant of educational policy, school committees, school principals, teachers, and some students are characterless.

Data analysis techniques used in this research is descriptive qualitative interpretative. Qualitative data analysis made it through three systematic steps before, during and after data collection (Suprayoga and Tabroni): (1) data reduction, is sorting, simplification, abstraction and transformation of data, 
(2) data is an activity to assemble, collate the information into a form that is simple, easy to understand, (3) drew the conclusion is the configuration of the field notes to test the truth, the validity of which is found in the field.

\section{DISCUSSION}

This study discusses the things below, namely:

1. Islamic Boarding School Assunnah spreading propaganda Islamiyah through tashfiyah (purification of Islam) and tarbiyah (coaching continuity) and educate generations of Muslim intellectuals who have aqidah straight worship properly and noble understanding salafussholeh.

a. Foundation Assunnah more emphasis on the four character Apostle in educating students with various models of moral/character, namely a) the integration of moral education/characters in learning, b) planting Uswah Hasanah method uswah hasanah, educate through ibrah, educating through mau'idhah, educate through discipline, educate through personality, c) attarghib wa at-tarhib.

b. Model Development of Character Education in Boarding School Foundation Assunnah form:

1) The value of fundamentals, instrumental and praxis is the character values developed at boarding school Assunnah Foundation.

2) The process of comprehensive development through learning, extracurricular activities, habituation, and cooperation with the community and the family is the character building process.

3) Habituation, advise, their rewards and sanctions, as well as exemplary of an independent character coaching methods.

4) Changes in behavior are more independent and disciplined.

Coaching is conducted at boarding school Assunnah Foundation in building self-reliance can be said to be successful students. This success can be seen from some fundamental changes of his students, namely:

1) The participation of students to become committee and to vote in the election activities rois/roisah,

2) The ability of the financial mengelolaan own,

3) Ability to effectively manage time and balance between learning time schools with school materials,

4) Allowing myself to wash clothes, cutlery, as well as my own ironing,

5) Allowing myself to be able to solve problems independently.

6) Allowing myself to always clean and tidy up kobong (room) itself,

7) Ability to limit communication with the family.

c. Internal and external obstacles encountered in the implementation of character building.
There are several problems facing the boarding school Assunnah Foundation in the implementation of an independent character building and discipline of students, including constraints that are internal (derived from the boarding school environment Assunnah Foundation) and external (originating outside the boarding school environment). Internal constraints include the following: a) is not optimal resource development educators and administrators boarding school. b) Lack of facilities and infrastructure. c) The number of unbalanced proportion between the numbers of teachers with students. d) Differences in family background of students.

2. Education characters developed is the integration of character education/moral learning, planting uswah hasanah using:

a. Exemplary method, as well as social learning theory of Albert Bandura is the most appropriate choice as the foundation of his theory. Since most human behavior is learned through imitation or presentation, modeling of behavior. In the boarding school environment, administrators and teachers play a role as a model or a leader for the students to imitate a particular character,

b. Methods of training and habituation, habituation activities conducted at boarding school environment Assunnah Foundation to foster the independence of students is as follows: a) Election rois/roisah submitted to the respective students. b) Financial management itself, c) Manage time effectively between the time to learn the material boarding schools, d) habituation to wash clothes, cutlery, as well as my own ironing, e) Habituation to be able to solve problems independently, f) Allowing myself to always clean up and tidy up their own, g) Restrictions on communication with family.

c. Method of educating through ibroh, through mauidhoh, educating through discipline, educate through selfreliance, and models at-targhib wa at-tarhib.

3. Attachment student-teachers, students-cleric, and studentscommittee has an important role in the moral formation of students in Islamic Boarding School Assunnah. The model affect the social intelligence, when the Prophet educate the friends with figuritas pattern, Prophet as a figure, so did mushrifs as a figure for the children so that the pattern of attachment is figuritas. Also emotional intelligence, also affect the emotional intelligence; mutual forgiveness, consciousness together, there is also always a hit, then called to dilerai advised, to forgive each other. Also attachment no effect with spiritual intelligence such as praying, reading the Qur'an, on occasion, diligent worship, the target hafalannya MTs MA 5 chapters and 10 chapters so that continues from MTs to the MA 15 juz minimum majority even have memorized the Quran when graduated from this boarding. 
a. Secure attachment, secure attachment helps student Assunnah Islamic boarding school in developing academic achievement and various other achievements, among which the Olympic champion mathematics, speech contest, write a straight dial, city level karate, taekwondo, tahsinul Qur'an, Olympics PASIAD, tahfidhul Quran, Quran memorized 30 chapters and various other championship.

b. Attachment and development of the faith / belief in God is marked stickiness students students-Islamic cleric Assunnah boarding school with their proximity, like brother and sister, parent-child and others. Stickiness it lasts until they finish studying and boarding at the Islamic boarding school Assunnah. Attachment students-cleric provides strong motivation to develop faith, especially belief in God, is because the administrators and chaplain / cleric always provide direction, guidance and advice.

c. Attachment and formation of characters of students, at the Islamic boarding school Assunnah develop its strategy in the form of Exploring and developing the potential of learners based on the intelligence of the heart, mind and spiritual as a form of attachment students-cleric / cleric, and students-board. Mentoring cleric / cleric to students poured on a series of activities, namely:

- Teaching and Learning Activities (KBM) at 07:00 to 14:00

- Qira'ah and Tahfidzul Qur'an after fajr and 'asr

- Tadarrus Qur'an before the Fard prayers and thereafter

- Tutoring and muraja'ah (self-learning) night.

- Fard prayer in congregation and qiyamullail

- Taushiyah Tsaqamah Islamiyah in week

- Remedial and enrichment every Saturday and Sunday

- Extracurricular activities every Saturday and public holidays include:

a. Outbound and outdoor studies

b. Khitobah Arab and foreign language (Arabic and English Study Club)

c. Practice computers and internet

d. Martial sport, table tennis, badminton, volleyball, indoor soccer, and swimming.

e. Islamic studies and sermons of scientific weekly weekly

4. Contributions Character Education at MTs-MA Boarding School Foundation Assunnah on Character Education in Indonesia.

a. Values Character Education in MTs-MA Boarding School Assunnah

There are 18 values in character education by the Ministry of Education, namely religious, honesty, tolerance, discipline, hard work, creative, independent, democratic, curiosity, the national spirit, recognize excellence, friendship / communicative, love peace, love reading, caring environmental, social care, responsibility, and peace. Of the 18 such values, 6 values are emphasized as character education in MTsMA Boarding School Assunnah, namely:

1) Religious, Religiosity in Islamic boarding school Assunnah become the dominant factor in social welfare students who become the findings in this study. Pupils with a high level of religiosity in all its dimensions help concerned to be more adaptive included in all activities and social fields so as to achieve social welfare.

2) To be honest, the pressure level of honesty in this institution so that santri always carry out the virtues and leave a crime in accordance with the understanding salafussholeh, as taught by the Apostle Muhammad saw, through the properties of the Prophet Muhammad, namely sidiq, amanah, tabligh and fathanah. In order to achieve the target of moral guidance, the boarding school environment Assunnah Foundation, in addition to be taught about the Al-Quran and Al-Hadith and noble values including honesty, also taught some of the books which the charged material morals, as a form of elaboration more detailed than the Qur'an and al-Hadith.

3) Discipline, the level of compliance was shown students the foundation following Assunnah with all the rules and other obligations in the activities of the boarding school, which is also regulated by law Assunnah Islamic Boarding School. That discipline and regulations governing all activities and activities of students while in Boarding School. Indicators to be as inspiration parameter value discipline students in boarding schools consist of; a) the attitude, behavior, appearance and how to use clothing of students. b) the timeliness of learning and praying. c) awareness of students about cleanliness, order and security in boarding schools. d) compliance duties.

4) Work hard, at the Islamic boarding school to develop its strategy in the form Assunnah explore and develop the potential of students based on the intelligence of the heart, mind and spiritual as hard work as a form of character education students. Mentoring cleric / cleric to students-santrinya students poured on a series of activities, namely:

- Teaching and Learning Activities (KBM) at 07:00 to $14: 00$

- Qira'ah and Tahfidzul Qur'an after Fajr and 'Asr

- Tadarrus Qur'an before the fard prayers and thereafter 
- Tutoring and muraja'ah (self-learning) night.

- Fard prayer in congregation and qiyamullail

- Taushiyah Tsaqamah Islamiyah each week

- Remedial and enrichment every Saturday and Sunday

5) Independent, coaching is conducted at boarding school Assunnah Foundation in building selfreliance can be said to be successful students. This success can be seen from some fundamental changes of his students, namely a) the participation of students to become committee and to vote in the election activities rois/roisah, b) the ability to manage own financial, c) the ability to manage time effectively and balanced between the time learning materials boarding schools, d) get used to wash clothes, cutlery, as well as my own ironing, e) to familiarize themselves to be able to solve problems independently, f) getting used to always clean and tidy up room itself, g) the ability to limit communication with the family.

6) Respect achievement, education and activities in Boarding School has always appreciated the achievements of students, from academic achievement, giftedness until the achievement of students, including the ability to memorize the Qur'an 5 chapters for students who sit in MTs, and 10 chapters for students sitting in the Supreme Court, the ability to develop a language of communication, namely Arabic and English, and the ability in academics with various achievements of students, and the ability of the various skills of students.

b. Contributions Character Education Boarding School Foundation Assunnah on Character Education in Indonesia.

1) Contribution of Islamic Character Education

Community Islamic Boarding School Assunnah on basic by tafaqquh fiddin (studying/reviewing religion) with the principle of al-muhafazhotu 'alaal qhodimissholeh wal akhdzu biljadidil ashlah (tradition maintain the good old and new traditions take better) with the understanding salafussholeh. This rule became the core values that underlie life Assunnah Islamic Boarding School. Existence Boarding School is established as animated by some niᄀlai distinctive character of Islamic education, among them is the understanding of the text of the Koran and the Hadith the Prophet (Salaf), obedience, independence of the discipline, sincerity and simplicity and islamic brotherhood. In the life of Islamic Boarding School Assunnah; between relations students, and between students and leaders (organizers, teachers, and administrators) are familial and respectful. Santri submission and obedience to the leader becomes absolute.

2) Contributions of Psychology Education in Character Education Students

Islamic Boarding School Assunnah apply the model of attachment as a substitute for parents of students with two counselors that mentors who do not live in a dorm and elders and mentors who live in dormitories and also mushrifs/musyrifah other than assigned, while assigned to guide personally, such as learning the night, friend chat, friend to confide in, so that there are standalone ust Abu Shomat, ustadah Francine, ustadah Nur'aini, ustadah Yati, and so to lead worship, hifdul Qur'an and also help the brothers in solving the problem, they just sleep problems at home, maybe even with their husbands over the children as' azam we preach.

\section{CONCLUSION}

Character education students in MTs-MA Boarding School Assunnah Cirebon is unique in educating its students, the notice of attachment students-administrators, studentsteachers and students-managers of schools, so that the manager and the preachers as a parent, as well as steakholders strengthen character building.

\section{REFERENCES}

[1] Dhofier, Zamakhsari. Tradisi Pesantren studi pandangan hidup Kyai dan visinya mengenai masa depan Indonesia. Jakarta: LP3SE. 2011

[2] Maksudin, Pendididikan Nilai Sistem Boarding School di Sekolah Menengah Pertama Islam Terpadu Abubakar Yogyakarta, Disertasi UIN Sunan Kalijaga, 2008.

[3] Baktiar, Boarding School dan Peranannya dalam Pendidikan Islam, 2013.

[4] Dhofier, Zamakhsari. Tradisi Pesantren studi pandangan hidup Kyai dan visinya mengenai masa depan Indonesia. Jakarta: LP3SE. 2011

[5] Umiarso \& Nurzazin, N. Pesantren di Tengah Arus Mutu Pendidikan menjawab problematika kontemporer Manajemen Mutu Pesantren. Semarang: RaSAIL Media Group. 2011

[6] Kevin Ryan \& Karen E. Bohlin., Building Character in Schools: Practical Ways to Bring Moral Instruction to Life. San Francisco: Jossey Bass. 1999

[7] Pusat Bahasa Departemen Pendidikan Nasional. Kamus Bahasa Indonesia. Jakarta: Pusat Bahasa. Cet. I. 2008

[8] Lickona, Thomas, Educating for Character: How Our School Can Teach Respect and Responsibility. New York, Toronto, London, Sydney, Aucland: Bantam books. 1991.

[9] Mulyani. Model integrasi tindak tutur direktif dalam penerapan pendidikan ahlaq mulia dan karakter bangsa bagi pelajar di SMA Jurnal Penelitian Inovasi dan Perekayasa Pendidikan, no.2 tahun ke 1, Agustus 2010. Puslitjaknov, Balitbang Kemendiknas

[10] Nicola Atwool, Nicola, Attachment Issues, Community and Family Studies, University of Otago. 1999 